\title{
Glycine Increases the Number of Somatostatin Receptors and Somatostatin-Mediated Inhibition of the Adenylate Cyclase System in the Rat Hippocampus
}

\author{
L. Puebla and E. Arilla \\ Unidad de Neuroendocrinología Molecular, Departamento de Bioquímica y Biología Molecular, Facultad de \\ Medicina, Universidad de Alcalá, Alcalá de Henares, Madrid, Spain
}

The glycine and somatostatin (SS) neurotransmission systems in the brain have been implicated in the function of sensory, motor, and nociceptive pathways. To investigate a possible relationship between these two components, we studied the influence of glycine on the binding of ${ }^{125} \mathrm{I}_{-} \mathrm{Tyr}^{11}$-SS to its receptors and on SS-like immunoreactivity (SSLI) levels in the rat hippocampus and frontoparietal cortex. An intracerebroventricular (i.c.v.) dose of 16 or $160 \mathrm{nmol}$ of glycine induced an increase in the total number of specific SS receptors in the hippocampus but not in the frontoparietal cortex at 15 min following injection, with no changes in the affinity constant. This effect seems to be mediated by inhibitory strychninesensitive glycine receptors since pretreatment with the antagonist strychnine $(80 \mu \mathrm{g} / 100 \mathrm{~g}$ body weight, intravenously) abolished this response. No significant changes in SSLI content were detected in either brain region of glycine- and strychnine plus glycine-treated rats as compared to control values. Since SS receptors are coupled via guanine nucleotide-binding $G$ proteins to the adenylyi cyclase (AC) system, we also examined the inhibitory effects of SS and the guanine nucleotide $\mathrm{Gpp}(\mathrm{NH}) \mathrm{p}$ on AC activity in hippocampal membranes of control, glycine- and strychnine plus glycine-treated rats since the increase in SS receptors was observed only in this brain area. No significant differences were observed for the forskolin (FK)stimulated AC enzyme activities in hippocampal membranes from all the experimental groups studied. In the hippocampus of the glycine- $(160 \mathrm{nmol})$ treated group, however, basal $\mathrm{AC}$ activity was significantly lower, and the capacity of SS to inhibit FK-stimulated $\mathrm{AC}$ activity was increased as compared to the control group. Pretreatment with strychnine prevented the increase in SS-mediated inhibition of $\mathrm{AC}$ activity. The functional activity of the inhibitory guanine nucleotide-binding protein $G_{i}$, as determined by the inhibitory effect of the stable GTP analogue Gpp(NH)p on FK-stimulated AC activity, was significantly higher in hippocampal membranes of glycine- (160 nmol) treated rats as compared to controls. This suggests that the increased inhibition of $\mathrm{AC}$ activity by SS in the glycine-treated group may be due to the increase in $G_{i}$ activity and/or the increase in the number of SS receptors observed. Alternatively, the greater $G_{i}$ activity may be responsible for the increased binding of ${ }^{125}{ }^{\text {I-Tyr }}{ }^{11}$-SS to its receptors observed after glycine administration. Altogether, these data suggest that the hippocampal somatostatinergic system can be regulated by strychnine-sensitive glycine receptors in the rat. (c) 1996 Wiley-Liss, Inc.

Key words: glycine, strychnine, somatostatin, G-protein, hippocampus

\section{INTRODUCTION}

Somatostatin (SS) and glycine are two inhibitory neurotransmitters in the mammalian central nervous system (CNS) which have been implicated in the function of sensory, motor, and nociceptive pathways (Epelbaum, 1986; Betz, 1991). Until recently, glycine was generally not considered to play a significant role in neurotransmission above the level of the mammalian brainstem. Several reports, however, have suggested that glycine can affect neuronal activity in higher brain regions (Raiteri et al., 1990; Schmidt and Taylor, 1990; Ito and Cherubini, 1991; Shirasaki et al., 1991). Immunocytochemical studies have shown that glycine-immunore-

Received July 10, 1995; accepted July 28, 1995.

Address reprint requests to E. Arilla, Unidad de Neuroendocrinología Molecular, Dept. de Bioquímica y Biología Molecular, Facultad de Medicina, Universidad de Alcalá, Alcalá de Henares, E-28871 Madrid, Spain. 
active fibers (Van den Pol and Gorcs, 1988) are present in the various brain regions known to contain SS-positive nerve terminals (Köhler and Chan-Palay, 1982; Joëls et al., 1990). Furthermore, a dense localization of SS receptors has been detected in the rat cerebral cortex and hippocampus (Srikant and Patel, 1981; Epelbaum et al., 1982; Czernik and Petrack, 1983; Reubi and Maurer, 1985), two brain regions which have been demonstrated to contain inhibitory glycine receptors (Van den Pol and Gorcs, 1988; Malosio et al., 1991; Naas et al., 1991; Becker et al., 1993; Siebler et al., 1993). Colocalization of SS and glycine has been characterized in amacrine cells of the retina (Smiley and Basinger, 1989). In addition, both glycine (Toth et al., 1983) and SS (Higuchi et al., 1984; Vezzani et al., 1991) have been shown to possess anticonvulsant properties. In view of all this, it is reasonable to consider a reciprocal functional link between the glycinergic and somatostatinergic systems. To date, there is no report concerning the influence of glycinergic neurotransmission on SS binding or on the ability of SS to inhibit adenylyl cyclase (AC) activity in the brain. The present study was thus undertaken in order to analyze the action of glycine on specific SS receptor binding and SS-like immunoreactivity (SSLI) content in the rat frontoparietal cortex and hippocampus. Since SS modulation of neural function involves the inhibition of $\mathrm{AC}$ activity through activation of SS receptors coupled via GTP-binding " $G$ " proteins to the enzyme (Schettini et al., 1989; Law et al., 1991), the density of the SS receptor binding sites was compared with SS-mediated inhibition of AC activity in hippocampal membranes from control, glycine-, and strychnine plus glycinetreated rats. In addition, we have measured the overall catalytic activity of the enzyme using forskolin (FK), an agent which potently stimulates the catalytic subunit of AC (Schettini et al., 1989). Furthermore, by using the stable GTP analogue 5'-guanylylimidodiphosphate, $[\mathrm{Gpp}(\mathrm{NH}) \mathrm{p}]$, we determined the functional activity of the $G_{i}$ proteins in the control, glycine, and glycine plus strychnine groups. In view of the rapid onset of glycine action in the CNS (Betz, 1991), rats from all experimental groups were sacrificed $15 \mathrm{~min}$ after the last drug injection.

\section{MATERIALS AND METHODS}

\section{Chemicals}

Synthetic $\mathrm{Tyr}^{11}$-SS and SS-14 were purchased from Universal Biologicals Ltd (Cambridge, U.K.); carrier-free $\mathrm{Na}^{125} \mathrm{I}$ (IMS $30,100 \mathrm{mCi} / \mathrm{ml}$ ) and rabbit antibody were purchased from the Radiochemical Centre (Amersham, U.K.); glycine, strychnine sulfate, bacitracin, bovine serum albumin (BSA), FK, phenylmethylsulfonyl fluoride (PMSF), 3-isobutyl-1-methylxanthine
(IBMX), ATP, GTP, Gpp[NH]p, creatine kinase, and creatine phosphate were all supplied by Sigma Química (Madrid, Spain). The rabbit antibody used in the radioimmunoassay technique was purchased from the Radiochemical Centre (Amersham, U.K.). This antiserum was raised in rabbits against SS-14 conjugated to BSA and is specific for SS, but since SS-14 constitutes the C-terminal portions of both SS-25 and SS-28, the antiserum does not distinguish between these three forms. Cross-reactivity with other peptides was less than $0.5 \%$. Crossreaction with several $\mathrm{SS}$ analogues demonstrated that neither the $\mathrm{N}$-terminal glycine nor the $\mathrm{C}$-terminal cysteine residue is required for antibody binding, suggesting that the antigen site is directed toward the central part of the molecule containing the tryptophan residue. The binding of SS-14 to this antibody does not depend on an intact disulfide bond in the molecule as breaking of the disulfide bond by reaction with $0.1 \%$ mercaptoethanol (boiling water bath, $5 \mathrm{~min}$ ) did not change the immunoreactivity of the peptide.

\section{Experimental Animals}

The animals used in this study were 30 Wistar rats weighing between 200 and $250 \mathrm{~g}$. Rats were maintained on a $12 \mathrm{hr}$ light/dark cycle $(0700-1900)$ and allowed free access to food. Glycine was dissolved in $0.9 \% \mathrm{NaCl}$ and administered intracerebroventricularly (i.c.v.) in a volume of $10 \mu \mathrm{l}$ according to the method described by Noble et al. (1967) at a dose of 16 or $160 \mathrm{nmol}$ of free base, as previously described (Danysz et al., 1989). Strychnine $(80 \mu \mathrm{g}$ free base/100 g body weight) was dissolved in saline and administered intravenously via the jugular vein in a volume of $100 \mu \mathrm{l} / 100 \mathrm{~g}$ body weight (Brown and Vale, 1975) 5 min before glycine administration. In all experiments, control animals received equivalent volumes of the corresponding vehicle. All rats were sacrificed by decapitation $15 \mathrm{~min}$ after the last drug injection. The brain was rapidly removed, and the frontoparietal cortex and hippocampus were dissected over ice.

\section{Tissue Extraction and SS Radioimmunoassay}

For SSLI measurements, the frontoparietal cortex and hippocampus were rapidly homogenized in $1 \mathrm{ml} 2 \mathrm{M}$ acetic acid using a Brinkman polytron (setting 5, $30 \mathrm{sec}$ ). The extracts were boiled for $5 \mathrm{~min}$ in a water bath, chilled in ice, and aliquots $(100 \mu \mathrm{l})$ were removed for protein determination (Patel and Reichlin, 1978). The homogenates were subsequently centrifuged at $15,000 \mathrm{~g}$ for $15 \mathrm{~min}$ at $4^{\circ} \mathrm{C}$, and the supernatant was neutralized with $2 \mathrm{M} \mathrm{NaOH}$. The extracts were then stored at $-70^{\circ} \mathrm{C}$ until assay. The SSLI content was determined in tissue extracts by a modified radioimmunoassay method (Patel and Reichlin, 1978), with a sensitivity limit of $10 \mathrm{pg} / \mathrm{ml}$. Incubation tubes prepared in duplicate contained $100-\mu 1$ 
samples of unknown or standard solutions of $0-500 \mathrm{pg}$ cyclic SS tetradecapeptide diluted in phosphate buffer ( $0.05 \mathrm{M}, \mathrm{pH} 7.2$ containing $0.3 \%$ BSA, $0.01 \mathrm{M}$ EDTA), $200 \mu \mathrm{l}$ of appropriately diluted anti-SS serum, $100 \mu \mathrm{l}$ of freshly prepared ${ }^{125} \mathrm{I}_{-} \mathrm{Tyr}^{11}$-SS diluted in buffer to give $6,000 \mathrm{cpm} /$ assay tube (equivalent to $5-10 \mathrm{pg}$ ), and enough buffer to give a final volume of $0.8 \mathrm{ml}$. All reagents, as well as the assay tubes, were kept chilled in ice before their incubation for $48 \mathrm{hr}$ at $4^{\circ} \mathrm{C}$. Separation of bound and free hormone was accomplished by the addition of $1 \mathrm{ml}$ dextran-coated charcoal (dextran T-70: 0.2\% w/v, Pharmacia, Uppsala, Sweden; charcoal Norit A: $2 \%$ w/v, Serva, Feinbiochemica, Heidelberg, Germany). Serial dilution curves for each brain area were parallel to the standard curve. The intra- and interassay coefficients of variation were 6.2 and $8.6 \%$, respectively.

\section{Binding Assay}

$\mathrm{Tyr}^{11}$-SS was radioiodinated by Chloramine-T iodination according to the method of Greenwood (Greenwood et al., 1963). The tracer was purified in a Sephadex G-25 fine column $(1 \times 100 \mathrm{~cm})$ equilibrated with $0.1 \mathrm{M}$ acetic acid containing BSA $0.1 \%(\mathrm{w} / \mathrm{v})$. The specific activity of the purified labeled peptide was about $600 \mathrm{Ci} / \mathrm{g}$.

Hippocampal and frontoparietal cortex membranes were prepared as previously described by Reubi et al. (1981). Protein concentration was assayed by the method of Lowry (Lowry et al., 1951), with BSA as a standard. Specific SS binding was measured according to the modified method of Czernik and Petrack (1983). Briefly, the membranes $(0.15 \mathrm{mg}$ protein $/ \mathrm{ml})$ were incubated in 250 $\mu l$ of a medium containing $50 \mathrm{mM}$ Tris- $\mathrm{HCl}$ buffer $(\mathrm{pH}$ 7.5 ), $5 \mathrm{mM} \mathrm{MgCl} 2,0.2 \%$ (w/v) BSA, and $0.1 \mathrm{mg} / \mathrm{ml}$ bacitracin with $250 \mathrm{pM}^{125} \mathrm{I}^{-\mathrm{Tyr}^{11}}{ }^{1} \mathrm{SS}$ either in the absence or presence of 0.01-10 nM unlabeled SS. After a 60 -min incubation at $30^{\circ} \mathrm{C}$, bound and free ligand were separated by centrifugation at $11,000 \mathrm{~g}$ for $2 \mathrm{~min}$, and the radioactivity in the resultant pellet was measured. Nonspecific binding was obtained from the amount of radioactivity bound in the presence of $10^{-7} \mathrm{M} \mathrm{SS}$ and represented about $20 \%$ of the binding observed in the absence of unlabeled peptide. This non-specific component was subtracted from the total bound radioactivity in order to obtain the corresponding specific binding.

\section{Evaluation of Radiolabeled Peptide Degradation}

The inactivation of ${ }^{125} \mathrm{I}_{-} \mathrm{Tyr}^{11}$-SS in the incubation medium after exposure to membranes was studied by measuring the ability of preincubated peptide to rebind to fresh membranes. Briefly, ${ }^{125} \mathrm{I}-\mathrm{Tyr}^{11}$-SS $(250 \mathrm{pM})$ was incubated with membranes from rat hippocampus and frontoparietal cortex $(0.15 \mathrm{mg}$ protein $/ \mathrm{ml})$ for $60 \mathrm{~min}$ at $30^{\circ} \mathrm{C}$. After this preincubation, aliquots of the medium were added to fresh membranes and incubated for an additional $60 \mathrm{~min}$ at $30^{\circ} \mathrm{C}$. The fraction of the added radiolabeled peptide which was specifically bound during the second incubation was measured and expressed as a percentage of the binding that had been obtained in control experiments performed in the absence of membranes during the preincubation period.

\section{Adenylyl Cyclase Assay}

$\mathrm{AC}$ activity was measured as previously reported (Houslay et al., 1976) with minor modifications. Briefly, hippocampal and frontoparietal cortex membranes $(0.06 \mathrm{mg} / \mathrm{ml})$ were incubated with $1.5 \mathrm{mM} \mathrm{ATP}$, $5 \mathrm{mM} \mathrm{MgSO}_{4}, 10 \mu \mathrm{M}$ GTP, an ATP-regenerating system $(7.5 \mathrm{mg} / \mathrm{ml}$ creatin phosphate and $1 \mathrm{mg} / \mathrm{ml}$ creatine kinase), $1 \mathrm{mM}$ IBMX, 0.1 mM PMSF, $1 \mathrm{mg} / \mathrm{ml}$ bacitracin, $1 \mathrm{mM}$ EDTA, and test substances $\left(10^{-4} \mathrm{M}\right.$ SS or $10^{-5} \mathrm{M} \mathrm{FK}$ ) in $0.1 \mathrm{ml}$ of $0.025 \mathrm{M}$ triethanolamine/ $\mathrm{HCl}$

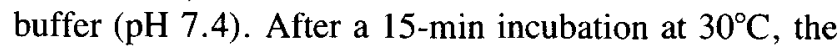
reaction was stopped by heating the mixture for $3 \mathrm{~min}$. After cooling, $0.2 \mathrm{ml}$ of an alumina slurry $(0.75 \mathrm{~g} / \mathrm{ml}$ in triethanolamine/ $\mathrm{HCl}$ buffer, $\mathrm{pH} \mathrm{7.4)} \mathrm{was} \mathrm{added,} \mathrm{and} \mathrm{the}$ suspension was centrifuged. The supernatant was taken for assay of cyclic AMP (cAMP) by the method of Gilman (1970). The SS concentration used was that necessary to achieve inhibition of rat (Schettini et al., 1989) and human (Bergström et al., 1991) brain AC activity. FK was used at a concentration that could effectively stimulate the catalytic subunit of rat AC (Schettini et al., 1989).

\section{Data Analysis}

The computer program LIGAND (Munson and Rodbard, 1980) was used to analyze the binding data. The use of this program enabled models of receptors that best fit the given sets of data to be selected. The same program was also used to present the data in the form of Scatchard plots and to compute values for receptor affinity $\left(K_{d}\right)$ and density $\left(B_{\max }\right)$ that best fit the sets of binding data for each rat. Statistical comparisons of all the data were carried out with one-way analysis of variance (ANOVA) and the Student Newman-Keuls test. Means among groups were considered significantly different when the $P$ value was less than .05 . Each individual experiment was performed in duplicate.

\section{RESULTS}

Glycine administration at a dose of 16 or $160 \mathrm{nmol}$ increased the specific binding of SS to rat hippocampal membranes 15 min after its i.c.v. injection as compared to control conditions (Table I; Fig. 1). When comparing the corresponding curves of ${ }^{125} \mathrm{I}_{-} \mathrm{Tyr}^{11}$-SS displacement by increasing concentrations of the unlabeled neuropep- 
TABLE I. Effect of Glycine (16 $\mathrm{nmol}$ or $160 \mathrm{nmol} / \mathrm{rat})$ and Strychnine $(80 \mu \mathrm{g} / 100 \mathrm{~g}$ Body Weight) Plus Glycine (160 nmol/rat) on Equilibrium Parameters for Somatostatin (SS) Binding to Rat Frontoparietal Cortex and Hippocampal Membranes ${ }^{\dagger}$

\begin{tabular}{|c|c|c|c|c|}
\hline \multirow[b]{3}{*}{ Groups } & \multicolumn{4}{|c|}{ SS receptors } \\
\hline & \multicolumn{2}{|c|}{ Hippocampus } & \multicolumn{2}{|c|}{ Frontoparietal cortex } \\
\hline & $B_{\max }$ & $\mathrm{K}_{\mathrm{d}}$ & $B_{\max }$ & $\mathrm{K}_{\mathrm{d}}$ \\
\hline Control & $391 \pm 12$ & $0.35 \pm 0.04$ & $449 \pm 30$ & $0.51 \pm 0.02$ \\
\hline Glycine $16 \mathrm{nmol}$ & $460 \pm 21^{*}$ & $0.35 \pm 0.02$ & $442 \pm 34$ & $0.44 \pm 0.05$ \\
\hline Control & $391 \pm 26$ & $0.39 \pm 0.04$ & $390 \pm 63$ & $0.45 \pm 0.05$ \\
\hline Glycine $160 \mathrm{nmol}$ & $521 \pm 29^{*}$ & $0.42 \pm 0.04$ & $440 \pm 56$ & $0.49 \pm 0.05$ \\
\hline Control & $410 \pm 24$ & $0.41 \pm 0.08$ & $427 \pm 31$ & $0.46 \pm 0.08$ \\
\hline Strychnine $(80 \mu \mathrm{g})$ plus glycine $(160 \mathrm{nmol})$ & $386 \pm 29$ & $0.38 \pm 0.06$ & $404 \pm 32$ & $0.52 \pm 0.07$ \\
\hline
\end{tabular}

${ }^{\dagger}$ Binding parameters were calculated from Scatchard plots by linear regression. Units for $\mathrm{K}_{\mathrm{d}}$ are $\mathrm{nM}$ and units for $B_{\max }$ are femtomoles of SS bound per $\mathrm{mg}$ of protein. The results are represented as the mean \pm SEM of five separate experiments, each performed in duplicate. Statistical comparison versus control: $* P<.05$.

tide, the binding data were significantly higher in the glycine-treated rats throughout the whole range studied (Fig. 1, left panel). Scatchard plots of the stoichiometric binding data were linear and essentially parallel (Fig. 1, right panel). Interpretation of these data with the LIGAND computer program resulted in the best fit for a model with one type of SS receptor. Hippocampal membranes from glycine-treated rats exhibited a significant increase in the maximum SS-binding capacity at both doses studied (Table I; Fig. 1). The corresponding $K_{d}$ values, however, remained unchanged after glycine administration. No changes in either the number or affinity of SS receptors were detected in frontoparietal cortex membranes of rats treated with 16 or $160 \mathrm{nmol}$ of glycine (Table I).

To assess whether glycine exerts a direct action on SS receptors, glycine $\left(10^{-5} \mathrm{M}\right)$ was included in the incubation medium at the time of the binding assay with hippocampal membranes from normal rats. The addition of glycine had no effect on the SS receptors from this brain area (data not shown).

Hippocampal or frontoparietal cortex membranes from each experimental group showed a similar peptide degradation capacity, and the values varied by no more than $10 \%$ among the experimental groups.

Since the rise in the number of SS receptors was observed only in the hippocampus and the effect was greater in rats treated with $160 \mathrm{nmol}(33.2 \%$ increase) than in those treated with $16 \mathrm{nmol}(17.6 \%$ increase), the functional coupling of SS receptors to the AC system was studied in hippocampal membranes from control rats and rats treated with $160 \mathrm{nmol}$ of glycine. The effect of SS on basal and FK-stimulated AC activity was markedly increased in hippocampal membranes from glycine (160 nmol)-treated rats as compared to control animals (Table II; Fig. 2). Basal AC activity was significantly decreased in rats treated with $160 \mathrm{nmol}$ of glycine as
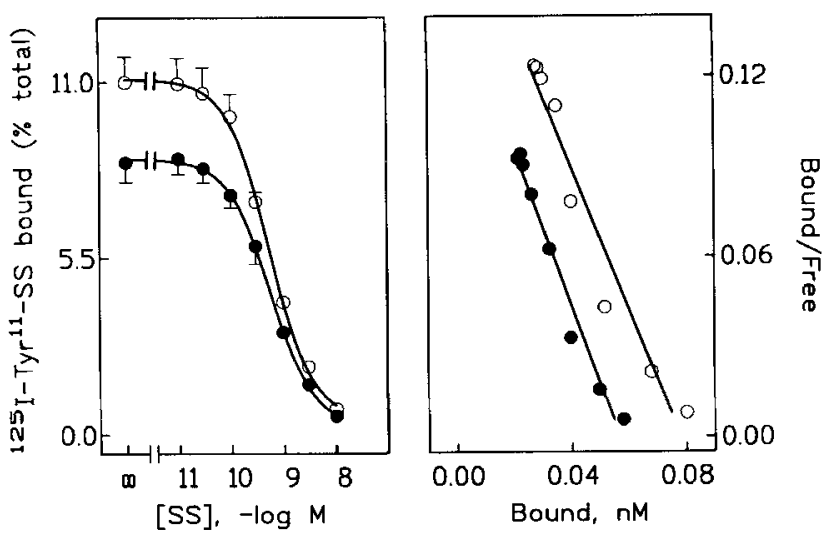

Fig. 1. Effect of $160 \mathrm{nmol}$ glycine, administered intracerebroventricularly, on somatostatin (SS) binding to rat hippocampal membranes at $15 \mathrm{~min}$ after drug injection. Left panel: Competitive inhibition of specific ${ }^{125} \mathrm{I}_{-\mathrm{Tyr}}{ }^{11}$-SS binding by unlabeled SS to hippocampal membranes. Membranes $(0.15 \mathrm{mg}$ protein $/ \mathrm{ml}$ ) were incubated for $60 \mathrm{~min}$ at $30^{\circ} \mathrm{C}$ in the presence of $250 \mathrm{pM}{ }^{125} \mathrm{I}-\mathrm{Tyr}^{11}-\mathrm{SS}$ and increasing concentrations of native peptide. Points correspond to values for the control rats $(\mathcal{O}, \mathrm{n}=5)$ and rats treated with $160 \mathrm{nmol}$ of glycine $(\mathrm{O}, \mathrm{n}=$ 5). Each point represents the mean \pm SEM of five separate experiments, each performed in duplicate. Right panel: Scatchard analysis of the binding data.

compared to control values (Table II; Fig. 2). To test if the observed changes were related to modifications in the expression of $\mathrm{AC}$, we measured the response of the enzyme to the diterpene FK, which is assumed to act directly upon the catalytic subunit. No significant differences were detected for FK-stimulated AC activity between the control and glycine-treated groups (Table II).

Further experiments explored the effect of glycine on the functional activity of $G_{i}$ proteins in rat hippocampal membranes by determining the ability of $G p p(N H) p$ 
TABLE II. Effect of Somatostatin (SS) $\left(10^{-4} \mathrm{M}\right)$ and Forskolin $(\mathrm{FK})\left(10^{-5} \mathrm{M}\right)$ on Brain Adenylyl Cyclase Activity (pmol cAMP/min/mg Protein) in Hippocampal Membranes From Control Rats $(\mathrm{n}=10)$ and Rats Treated With Glycine $(160 \mathrm{nmol})(\mathrm{n}=5)$ or Strychnine $\left(80 \mu \mathrm{g} / 100 \mathrm{~g}\right.$ Body Weight) plus Glycine $(160 \mathrm{nmol})(\mathrm{n}=5)^{\dagger}$

\begin{tabular}{lccccc}
\hline & \multicolumn{2}{c}{ Glycine } & & \multicolumn{2}{c}{ Strychnine + glycine } \\
\cline { 2 - 3 } \cline { 6 - 7 } & Control & Treated & & Control & Treated \\
\hline Basal activity & $245 \pm 11$ & $188 \pm 11^{* *}$ & & $242 \pm 13$ & $253 \pm 17$ \\
$\quad+10^{-4}$ M SS & $169 \pm 12$ & $104 \pm 5^{* *}$ & & $176 \pm 15$ & $177 \pm 15$ \\
$\%$ SS inhibition of basal activity & $31 \pm 4$ & $45 \pm 2^{*}$ & & $27 \pm 3$ & $30 \pm 3$ \\
$\quad+10^{-5}$ M FK & $868 \pm 44$ & $818 \pm 20$ & & $852 \pm 30$ & $871 \pm 51$ \\
Fold FK stimulation over basal & $3.5 \pm 0.3$ & $4.3 \pm 0.3$ & & $3.5 \pm 0.2$ & $3.2 \pm 0.1$ \\
$\quad+10^{-5}$ M FK $+10^{-4}$ M SS & $605 \pm 50$ & $422 \pm 24^{*}$ & & $584 \pm 36$ & $629 \pm 42$ \\
$\%$ SS inhibition of FK stimulation & $30 \pm 4$ & $48 \pm 3^{* *}$ & & $29 \pm 3$ & $28 \pm 2$ \\
\hline
\end{tabular}

${ }^{\dagger}$ Values represent the mean \pm SEM of five separate experiments, each performed in duplicate. Statistical comparison versus control: ${ }^{*} P<.05,{ }^{*} P<.01$.

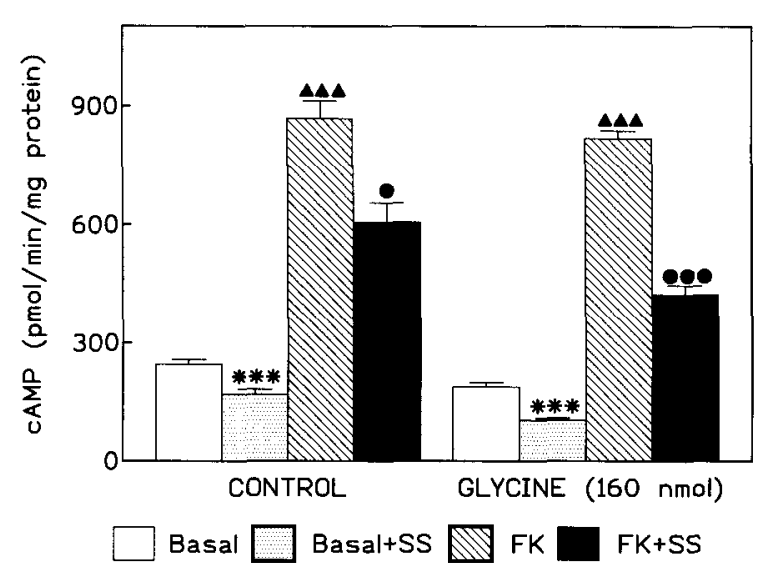

Fig. 2. Comparison of the ability of somatostatin (SS) to inhibit adenylyl cyclase (AC) activity in hippocampal membranes from control rats $(n=5)$ and rats treated with an intracerebroventricular dose of $160 \mathrm{nmol}$ of glycine at $15 \mathrm{~min}$ after injection. Membrane preparations were incubated with or without $S S\left(10^{-4} \mathrm{M}\right)$ in the absence (basal) or presence of $10^{-5}$ $\mathrm{M}$ forskolin (FK). Data are expressed as the mean \pm SEM of five separate experiments, each performed in duplicate. Statistical analysis was performed by ANOVA. $\boldsymbol{\Delta} \mathbf{\Delta} \boldsymbol{\Delta} P<.001$ : comparison between basal and FK-stimulated groups. ***P< .001 : comparison between basal and SS-treated groups. $P<$ $.05,00 P<.001$ : comparison between FK and FK + SS groups.

to inhibit FK $\left(3 \times 10^{-6} \mathrm{M}\right)$-stimulated AC activity, an effect that has been used by other investigators as a measure of $G_{i}$ function in membranes prepared from different tissues (Young et al., 1981). Hippocampal membranes derived from control rats yielded a characteristic biphasic response curve, as shown in Figure 3, which is assumed to be the result of $G_{i}$ protein activation at lower concentrations of $\mathrm{Gpp}(\mathrm{NH}) \mathrm{p}$ followed by $\mathrm{G}_{\mathrm{s}}$ protein activation at higher concentrations. Gpp(NH)p decreased FK-stimulated $\mathrm{AC}$ activity with a maximum inhibition observed at $10^{-7} \mathrm{M}$ in control animals. The inhibitory effect of $\mathrm{Gpp}(\mathrm{NH}) \mathrm{p}$ on FK-stimulated AC activity was markedly increased in hippocampal membranes from glycinetreated rats (Fig. 3).

Pretreatment with strychnine, a selective and competitive antagonist of glycine receptors, prevented the changes in SS receptors (Table I; Fig. 4), SS-mediated inhibition of $\mathrm{AC}$ activity (Table II), and $\mathrm{G}_{\mathrm{i}}$ function (Fig. 3 ) induced by glycine in hippocampal membranes.

SSLI content in the frontoparietal cortex or hippocampus was unaffected by glycine administration or by pretreatment with strychnine (Table III).

\section{DISCUSSION}

This study demonstrates for the first time that the i.c.v. administration of glycine induces an increase in the number of SS receptors, an increase in the functional activity of $G_{i}$ proteins, and a greater SS-mediated inhibition of AC activity, with no changes in SSLI content, in the hippocampus but not the frontoparietal cortex of the rat. The present data suggest that hippocampal SS receptors may be modulated by glycine in vivo. This regulation may reflect a positive feedback mechanism further enhancing the modulatory effects of glycine on SS neurotransmission.

The SSLI content and the equilibrium parameters of the SS receptors in the hippocampus and frontoparietal cortex of control rats were similar to those previously reported by others (Epelbaum et al., 1982; Pitkänen et al., 1986). Although the Scatchard plots of the stoichiometric data appear to be linear, this is no proof for receptor homogeneity. Indeed, it has been demonstrated for many years that SS binding in rat brain is heterogeneous (Reubi, 1984). It has recently been demonstrated that there are five cloned SS receptors which appear to be expressed in the brain (Bruno et al., 1993) and which all have similar high affinity for SS (Bell and Reisine, 


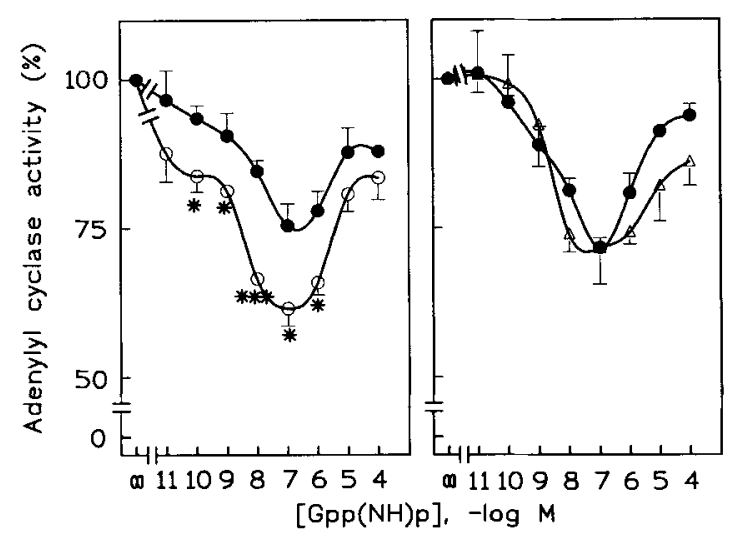

Fig. 3. Dose-effect curves for $5^{\prime}$-guanylylimidodiphosphate [Gpp(NH)p]-mediated inhibition of adenylyl cyclase (AC) activity in rat hippocampal membranes from control $(O ; n=5$ in each group), glycine-treated (160 nmol, i.c.v.) $(\bigcirc, \mathrm{n}=5)$, and strychnine $(80 \mu \mathrm{g} / 100 \mathrm{~g}$ body weight, i.v.) plus glycine (160 nmol, i.c.v.) -treated rats $(\Delta, n=5)$. The effect of $\mathrm{Gpp}(\mathrm{NH}) \mathrm{p}$ on $\mathrm{AC}$ activity was studied in the presence of $3 \times$ $10^{-6} \mathrm{M}$ forskolin (FK) and the indicated concentrations of $\mathrm{Gpp}(\mathrm{NH}) \mathrm{p}$. Data are expressed as a percentage of FK-stimulated AC activity in the absence of $\operatorname{Gpp}(\mathrm{NH}) \mathrm{p}(100 \%)$. The results are given as the mean \pm SEM of five separate determinations, each performed in duplicate. Statistical comparison versus control: $* P<.05 ; * * * P<.001$.

1993). Thus, a linear Scatchard plot indicates only that the labeled sites have similar affinity for the radioligand used.

A relatively high concentration of $\mathrm{SS}\left(10^{-4} \mathrm{M}\right)$ was required to produce inhibition of $A C$ activity. This same SS concentration was used by Schettini et al. (1989) and Bergström et al. (1991) in their studies on SS-mediated inhibition of $\mathrm{AC}$ activity in the rat and human brain. This concentration is three log units higher than that necessary

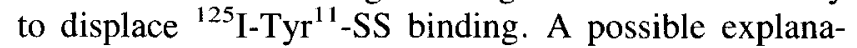
tion for this discrepancy may lie in the observation that $\mathrm{G}$ proteins can modulate the affinity of SS receptors and/or the coupling to the effector system (AC among others). In this respect, Enjalbert et al. (1983) demonstrated that the mobilization of the G protein by GTP reduces the SS receptor affinity for the neuropeptide in cerebral cortical cells. Indeed, in the presence of GTP necessary to couple the SS receptor to the AC catalytic subunit, the SS receptor may shift from an apparent high-affinity state (observed in binding studies) to an apparent low-affinity state (observed in AC studies).

Although it is early to speculate on the molecular mechanism of the glycine-mediated increase in the number of SS receptors, the glycine receptors seem to mediate the action of this neurotransmitter since the changes induced by glycine on the SS receptor/effector system
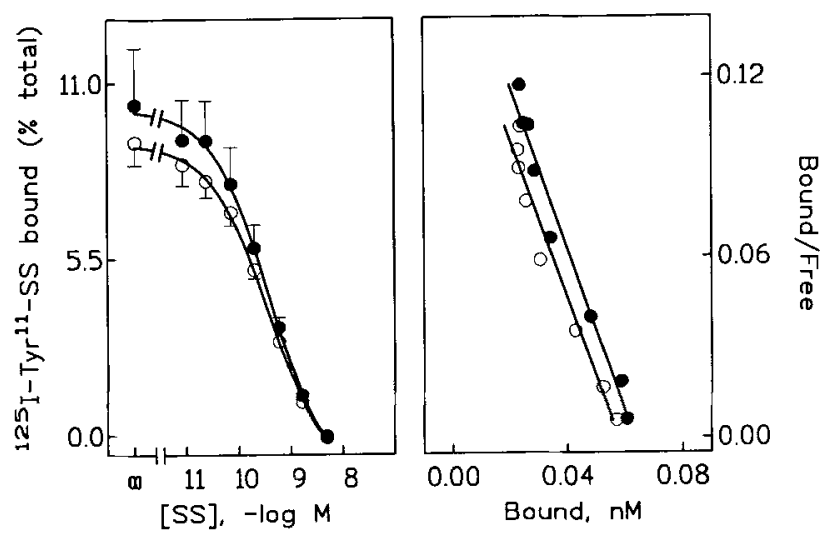

Fig. 4. Effect of pretreatment with strychnine $(80 \mu \mathrm{g} / 100 \mathrm{~g}$ body weight, i.v.) administered $5 \mathrm{~min}$ before glycine (160 nmol, i.c.v.) on somatostatin (SS) binding to rat hippocampal membranes at $15 \mathrm{~min}$ after the last drug injection. Left panel: Competitive inhibition of specific ${ }^{125} \mathrm{I}-\mathrm{Tyr}^{11}$-SS binding by unlabeled SS to hippocampal membranes. Membranes $(0.15 \mathrm{mg}$ protein $/ \mathrm{ml}$ ) were incubated for $60 \mathrm{~min}$ at $30^{\circ} \mathrm{C}$ in the presence of $250 \mathrm{pM}{ }^{125} \mathrm{I}_{-\mathrm{Tyr}^{11}}{ }^{-\mathrm{SS}}$ and increasing concentrations of native peptide. Points correspond to values for the control rats $(O, \mathrm{n}=5)$ and rats treated with strychnine plus glycine $(O$, $\mathrm{n}=5$ ). Each point represents the mean \pm SEM of five separate experiments, each performed in duplicate. Right panel: Scatchard analysis of the binding data.

TABLE III. Effect of Glycine (16 nmol or $160 \mathrm{nmol} / \mathrm{Rat})$ and Strychnine (80 $\mu \mathrm{g} / 100 \mathrm{~g}$ Body Weight) Plus Glycine (160 nmol/Rat) on Somatostatin-Like Immunoreactivity (SSLI) Concentration in the Rat Frontoparietal Cortex and Hippocampus*

\begin{tabular}{lrc}
\hline & \multicolumn{2}{c}{ SSLI $(\mathrm{ng} / \mathrm{mg}$ protein) } \\
\cline { 2 - 3 } Groups & Hippocampus & Frontoparietal cortex \\
\hline Control & $11.72 \pm 1.79$ & $10.41 \pm 1.66$ \\
Glycine $16 \mathrm{nmol}$ & $9.48 \pm 2.12$ & $9.90 \pm 1.81$ \\
Control & $13.21 \pm 0.74$ & $10.26 \pm 1.37$ \\
Glycine $160 \mathrm{nmol}$ & $10.21 \pm 2.02$ & $13.68 \pm 1.28$ \\
Control & $12.17 \pm 0.48$ & $15.62 \pm 2.29$ \\
Strychnine $(80 \mu \mathrm{g})$ & & \\
$\quad$ plus glycine $(160 \mathrm{nmol})$ & $15.99 \pm 1.87$ & $16.50 \pm 2.66$ \\
\hline
\end{tabular}

$*$ The results are represented as the mean \pm SEM of five separate experiments, each performed in duplicate.

were effectively antagonized by pretreatment with the alkaloid strychnine. In addition, the increase in tracer binding was not due to a direct effect of glycine on SS receptors since no change in ${ }^{125} \mathrm{I}-\mathrm{Tyr}^{11}$-SS binding was detected following incubation of fresh hippocampal membranes with glycine. The interaction of glycine with its receptor causes neuronal hyperpolarization by gating an ion channel selective for chloride, an effect which is specifically blocked by strychnine (Curtis et al., 1968). 
It is possible that hyperpolarization mediated by chloride channels coupled to glycine receptors is an important factor in the action of glycine on the SS receptor/effector system. At present, there is evidence supporting the hypothesis that changes in membrane polarization may induce modifications in the number of receptors present in that membrane (Liles and Nathanson, 1987).

The question arises as to whether the effect of glycine on the ${ }^{125} \mathrm{I}-\mathrm{Tyr}^{11}$-SS receptors is a result of a direct interaction of the glycinergic system on the somatostatinergic system or if it is mediated through interactions between SS and other neurotransmitters whose release can be modified by glycine. Several reports of strychnine-sensitive, glycine-induced norepinephrine and acetylcholine release from rat hippocampus have appeared (Raiteri et al., 1990; Schmidt and Taylor, 1990). The site at which glycine acts to produce norepinephrine or acetylcholine release in the hippocampus is pharmacologically similar to the glycine receptor of the mammalian spinal cord and is not related to the glycine site associated with the NMDA subtype of glutamate receptors (Schmidt and Taylor, 1990). Since the observed changes in SS binding are detected in an area rich in noradrenergic and cholinergic innervation (Delfs et al., 1984; Milner and Bacon, 1989), it can be speculated that the acute effects of glycine treatment on SS receptor binding in the hippocampus may be a result of SS-noradrenaline and/or SS-acetylcholine interactions. In this regard, our group of investigation has previously demonstrated that both the $\alpha_{1}$-adrenergic and the cholinergic nicotinic systems induce an increase in the number of SS receptors in the rat hippocampus (Barrios et al., 1990; López-Sañudo and Arilla, 1994).

The lack of effect of glycine on SS receptors in the frontoparietal cortex indicates the existence of regional differences in the interactions between glycine and SS. This difference could possibly be due to regional differences in the density of the glycine receptors. Variants of the $\alpha$ subunit which forms part of the glycine receptor$\alpha_{1}, \alpha_{2}$, and $\alpha_{3^{-}}$-have recently been identified by cDNA cloning in rodent and human CNS (Kuhse et al., 1990). In situ hybridization studies have demonstrated regional differences in the expression of these different glycine receptor $\alpha$ subunits (Malosio et al., 1991). The expression of $\alpha_{2}$ mRNA was detected in the dentate gyrus and $\mathrm{CA} 2, \mathrm{CA} 3$, and CA4 regions of the rat hippocampus at moderate levels, whereas in the cerebral cortex, $\alpha_{2}$-positive cells appeared to be largely confined to the deeper layer of lamina VI. Furthermore, expression of $\alpha_{3}$ mRNA was consistently observed throughout the hippocampal formation, whereas only the infralimbic cortex contained $\alpha_{3}$ transcripts. As the $\alpha_{3}$ subunit forms strychnine-sensitive chloride channels upon expression in $\mathrm{Xe}$ nopus oocytes, it has been considered a ligand-binding subunit of a strychnine-sensitive adult-type glycine receptor (Kuhse et al., 1990).

Since cerebral SS receptors are coupled via inhibitory $G_{i}$ proteins to different cellular effector systems (Law et al., 1991), an analysis of $\mathrm{G}_{\mathrm{i}}$ protein function was carried out by activating $G_{i}$ proteins directly with low concentrations of the stable GTP analogue Gpp(NH)p. Glycine administration at a dose of $160 \mathrm{nmol}$ induced an increase in functional $G_{j}$ activity as compared to control values. $G$ proteins contain three subunits $(\alpha, \beta, \gamma)$ which undergo dissociation when activated (Gilman, 1987). Several studies have demonstrated that hormone-sensitive $\mathrm{G}$ proteins are regulated by $\mathrm{Cl}^{-}$ions (Sternweis et al., 1986; Higashijima, 1992). $\mathrm{Cl}^{-}$ions have been shown to potentiate dissociation of the $G_{i}$ protein into $\alpha$ and $\beta \gamma$ subunits (Sternweis et al., 1986). Since glycine activates a selective $\mathrm{Cl}^{-}$ion channel through interaction with its receptors, such a regulatory effect of $\mathrm{Cl}^{-}$ions may explain the increase in $G_{i}$ protein functionality observed in the present study. $G_{0}$ proteins have also been shown to be regulated by $\mathrm{Cl}^{-}$(Higashijima et al., 1987). Since SS receptors are coupled to the inhibition of $\mathrm{Ca}^{2+}$ channels apparently through interaction with $\mathrm{G}_{\mathrm{o}}$ protein and SS binding has been demonstrated to be dependent on the extracellular $\mathrm{Ca}^{2+}$ concentration (Susini et al., 1985), it is tempting to speculate that the increase of SS receptors in glycine-treated rats may be related to changes in $\mathrm{Ca}^{2+}$ concentration resulting from the activation of $\mathrm{G}_{\mathrm{o}}$.

Glycine administration decreased basal AC activity as compared to control values. The increase in $G_{i}$ function induced by glycine administration may be responsible for this effect. The FK-stimulated AC activity, however, was similar in hippocampal membranes of control and glycine-treated rats, indicating that the catalytic subunit of $\mathrm{AC}$ is intact. The capacity of $10^{-4} \mathrm{M}$ SS to inhibit basal and FK-stimulated AC activity is significantly greater in rats treated with $160 \mathrm{nmol}$ of glycine than in the control animals. This increased sensitivity of AC to SS caused by glycine administration may be a consequence of the rise in the number of SS receptors observed. Alternatively, the increase in $G_{i}$ functional activity may participate in the increased SS-mediated inhibition of the enzyme, although it is highly probable that a combination of both factors is involved.

The functional significance of the present results is unknown. Immunohistochemically, glycine receptors have been preferentially localized to the apical dendrites of pyramidal neurons in layers III and V of the hippocampus (Van den Pol and Gorcs, 1988). In this same brain area, immunohistochemical studies have revealed many SS-containing interneurons (Köhler and Chan-Palay, 1982; Joëls et al., 1990) and a profuse network of intrinsic and extrinsic SS-containing fibers which appear 
to project to pyramidal and granule neurons (Joëls et al., 1990). In addition, SS receptors have also been described in pyramidal and granule neurons (Palacios et al., 1986). It is well established that SS (Watson and Pittman, 1988; Schweitzer et al., 1993) and glycine (Ito and Cherubini, 1991; Shirasaki et al., 1991) inhibit hippocampal CAl pyramidal neurons. In addition, the anticonvulsant effect of SS and glycine has been demonstrated electophysiologically in the hippocampus (Toth et al., 1983; Higuchi et al., 1984; Pitkänen et al., 1986; Vezzani et al., 1991). Because of these overlapping biological effects, the present results suggest that there may be interactions at multiple levels which allow these neurotransmitters to affect and augment the action of one another.

\section{ACKNOWLEDGMENTS}

This work was supported by a grant from the Dirección General de Investigación Científica y Técnica of Spain.

\section{REFERENCES}

Barrios V, Rodríguez-Sanchez MN, Colas B, Arilla E (1990): Effects of acute nicotine and mecamylamine administration on somatostatin concentration and binding in the rat brain. Eur J Pharmacol 179:263-270.

Becker CM, Betz H, Schröder H (1993): Expression of inhibitory glycine receptors in postnatal rat cerebral cortex. Brain Res 606:220-226.

Bell GI, Reisine T (1993): Molecular biology of somatostatin receptors. Trends Neurosci 16:34-38.

Bergström L, Garlind A, Nilsson L, Alafuzoff I, Fowler CJ, Winblad B, Cowburn RF (1991): Regional distribution of somatostatin binding and modulation of adenylyl cyclase activity in Alzheimer's disease brain. J Neurol Sci 105:225-233

Betz H (1991): Glycine receptors: heterogeneous and widespread in the mammalian brain. Trends Neurosci 14:458-461.

Brown M, Vale W (1975): Central nervous system effects of hypothalamic peptides. Endocrinology 96:1333-1336

Bruno JF, Xu Y, Song J, Berelowitz M (1993): Tissue distribution of somatostatin receptor subtype ribonucleic acid in the rat. Endocrinology 133:2561-2567.

Curtis DR, Hosli L, Johnston GAR (1968): A pharmacological study of the depression of spinal neurons by glycine and related amino acids. Exp Brain Res 6:1-18.

Czernik AJ, Petrack V (1983) Somatostatin receptor binding in rat cerebral cortex. Characterization using a nonreducible somatostatin analog. J Biol Chem 285:5525-5530.

Danysz W, Wroblewski JT, Brooker G, Costa E (1989): Modulation of glutamate receptors by phencyclidine and glycine in the rat cerebellum: cGMP increase in vivo. Brain Res 479:270-276.

Delfs JR, Zhu CJ, Dichter MA (1984): Coexistence of acetylcholinesterase and somatostatin-like immunoreactivity in neurons cultured from rat cerebrum. Science 223:61-63.

Enjalbert A, Rasolonn-Janahary R, Moyse E, Kordon C, Epelbaum J (1983): Guanine nucleotide sensitivity of $\left[{ }^{125} \mathrm{I}\right]$-iodo-N-Tyr-so- matostatin binding in rat adenohypophysis and cerebral cortex. Endocrinology 113:822-824.

Epelbaum J (1986): Somatostatin in the central nervous system: physiology and pathological modifications. Prog Neurobiol 27:63100.

Epelbaum J, Tapia-Arancibia L, Kordon C, Enjalbert A (1982): Characterization, regional distribution and subcellular distribution of ${ }^{125} \mathrm{I}-\mathrm{Tyr}^{1}$-somatostatin binding sites in rat brain. J. Neurochem 38:1515-1523.

Gilman AG (1970): A protein binding assay for adenosine $3^{\prime} 5^{\prime}$-cyclic monophosphate. Proc Natl Acad Sci USA 67:305-312.

Gilman AG (1987): G-proteins: transducers of receptor-generated signals. Annu Rev Biochem 56:615-649.

Greenwood FC, Hunter WM, Glover JS (1963) The preparation of ${ }^{131}$ I-labeled human growth hormone of high specific radioactivity. Biochem J 89:114-123.

Higashijima T (1992): Effects of chloride ion on the activation of $G$ proteins. Folia Pharmacol Japon 99:267-274.

Higashijima T, Ferguson KM, Sternweis PC (1987): Regulation of hormone-sensitive GTP-dependent regulatory proteins by chloride. J Biol Chem 262:3597-3602.

Higuchi T, Kokubu T, Sikand GS, Wada JA, Friesen HG (1984): A study of somatostatin receptors in amygdaloid-kindled rat brain. J Neurochem 43:1271-1276.

Houslay MD, Metcalfe JC, Warren GB, Hesketh TR, Smith GA (1976): The glucagon receptor of rat liver plasma membranes can couple to adenylate cyclase without activating it. Biochim Biophys Acta 436:489-494.

Ito S, Cerubini E (1991): Strychnine-sensitive glycine responses of neonatal rat hippocampal neurones. J Physiol (Lond) 440:6783.

Joëls M, Madamba SG, Moore SD, Morrison JH, Siggins GR (1990): Somatostatin immunohistochemistry of hippocampal slices with Lucifer yellow-stained pyramidal neurons responding to somatostatin. Regul Pept 28:215-221.

Köhler C, Chan-Palay V (1982): Somatostatin-like immunoreactive neurons in the hippocampus: an immunocytochemical study in the rat. Neurosci Lett 34:259-264.

Kuhse J, Schmieden V, Betz H (1990): Identification and functional expression of a novel ligand binding subunit of the inhibitory glycine receptor. J Biol Chem 265:22317-22320.

Law S, Manning D, Reisine T (1991): Identification of the subunits of GTP-binding proteins coupled to somatostatin receptors. J Biol Chem 266:17885-17897.

Liles WC, Nathanson NM (1987): Regulation of muscarinic acetylcholine receptor number in cultured neuronal cells by chronic membrane depolarization. J Neurosci 7:2556-2563.

López-Sañudo S, Arilla E (1994): Changes in $\alpha_{1}$-adrenergic neurotransmission alter the number of somatostatin receptors in the rat hippocampus. Neurosci Lett 177:107-110.

Lowry OH, Rosebrough NJ, Farr AL, Randall RJ (1951): Protein measurement with Folin phenol reagent. J Biol Chem 193:265275.

Malosio ML, Marquèze-Pouey B, Kuhse J, Betz H (1991): Widespread expression of glycine receptor subunit mRNAs in the adult and developing rat brain. EMBO J 10:2401-2409.

Milner TA, Bacon CE (1989): Ultrastructural localization of tyrosine hydroxylase-like immunoreactivity in the rat hippocampal formation. J Comp Neurol 281:479-495.

Munson PJ, Rodbard D (1980): LIGAND: a versatile computerized approach for characterization of ligand binding systems. Anal Biochem 107:220-239.

Naas E, Zilles K, Gnahn H, Betz H, Becker CM, Schröder H (1991): 
Glycine receptor immunoreactivity in rat and human cerebral cortex. Brain Res 561:139-146.

Noble EP, Wurtman RJ, Axelrod J (1967): A simple and rapid method for injecting $\mathrm{H}^{3}$-norepinephrine into the lateral ventricle of the rat brain. Life Sci 6:281-291

Palacios JM, Reubi JC, Maurer R (1986): Somatostatin receptors in rat hippocampus: localization to intrinsic neurons. Neurosei Lett 67:169-174.

Patel JC, Reichlin S (1978): Somatostatin in hypothalamus, extrahypothalamic brain and peripheral tissues of the rat. Endocrinology 102:523-531.

Pitkänen A, Sirviö J, Jolkkonen J, Riekkinen P (1986): Somatostatinlike immunoreactivity and somatostatin receptor binding in rat brain before and after pentylenetetrazol-induced convulsion. Neuropeptides 7:63-71.

Raiteri M, Fontana G, Fedel E (1990): Glycine stimulates [ $\left.{ }^{3} \mathrm{H}\right]-$ noradrenaline release by activation of a strychnine-sensitive receptor in rat hippocampus. $\mathrm{Br} \mathrm{J}$ Pharmacol 184:239-250.

Reubi JC (1984): Evidence for two somatostatin-14 receptor types in rat brain cortex. Neurosci Lett 49:259-263.

Reubi JC, Maurer R (1985): Autoradiographic mapping of somatostatin receptors in the rat central nervous system and pituitary. Neuroscience 15:1183-1193.

Reubi JC, Perrin MH, Rivier JE, Vale V (1981): High affinity binding sites for the somatostatin-28 analogue in rat brain. Life Sci 28:2191-2198.

Schettini G, Florio T, Meucci O, Landolfi E, Grimaldi M, Ventra C, Marino A (1989): Somatostatin inhibition of adenylate cyclase activity in different brain areas. Brain Res 492:65-71.

Schmidt CJ, Taylor VL (1990): Strychnine-sensitive, glycine-induced release of $\left[{ }^{3} \mathrm{H}\right]$ norepinephrine from rat hippocampal slices. $\mathrm{J}$ Neurochem 54:2077-2081.

Schweitzer P, Madamba S, Champagnat J, Siggins, GR (1993): Somatostatin inhibition of hippocampal CA1 pyramidal neurons: mediation by arachidonic acid and its metabolites. J Neurosci 13:2033-2049
Shirasaki T, Klee MR, Nakaye T, Akaike N (1991): Differential blockade of bicuculline and strychnine on GABA- and glycineinduced responses in dissociated rat hippocampal pyramidal cells. Brain Res 561:77-83.

Siebler M, Pekel M, Köller H, Müller HW (1993): Strychnine-sensitive glycine receptors in cultured primary neurons from rat neocortex. Dev Brain Res 73:289-292.

Smiley JF, Basinger SF (1989): Glycine high-affinity uptake labels a subpopulation of somatostatin-like immunoreactive cells in the Rana pipiens retina. Brain Res 495:31-44.

Srikant CB, Patel YC (1981): Somatostatin receptors: identification and characterization in rat brain membranes. Proc Natl Acad Sci USA 78:3930-3934.

Sternweis PC (1986): The purified $\alpha$ subunits of $G_{o}$ and $G_{i}$ from bovine brain require $\beta \gamma$ for association with phospholipid vesicles. J Biol Chem 261:631-637.

Susini C, Esteve JP, Vaysse N, Ribet A (1985): Calcium dependence of somatostatin binding to receptors. Peptides 6:831-833.

Toth E, Lajtha A, Sarhan S, Seiler N (1983): Anticonvulsant effects of some inhibitory neurotransmitter amino acids. Neurochem Res 8:291-302.

Van den Pol AN, Gorcs T (1988): Glycine and glycine receptor immunoreactivity in brain and spinal cord. J Neurosci 8:472-492.

Vezzani A, Serafini R, Stasi MA, Vigano G, Rizzi M, Samanin R (1991): A peptidase-resistant cyclic octapeptide analogue of somatostatin (SMS 201-995) modulates seizures induced by quinolinic and kainic acids differently in the rat hippocampus. Neuropharmacology 30:345-352.

Watson TWJ, Pittman QJ (1988): Pharmacological evidence that somatostatin activates the M-current in hippocampal pyramidal neurons. Neuroscience Lett 91:172-176.

Young P, Kirkham DM, Murphy GJ, Cawthorne MA (1981): Evaluation of inhibitory guanine nucleotide regulatory protein $G_{i}$ function in hepatocyte and liver membranes from obese Zucker (fa/fa) rats and their lean (fa/?) littermates. Diabetologia 34: $565-569$. 